\title{
ЕТАПИ ВПРОВАДЖЕННЯ НАВЧАЛЬНОГО ДІАЛОГУ У ПРОЦЕС ВИВЧЕННЯ ІНОЗЕМНИХ МОВ МАЙБУТНІМИ ГІРНИКАМИ
}

Бакум 3. П., Лапіна В. О. Етапи впровадження навчального діалогу у процес вивчення іноземних мов майбутніми гірниками.

У статті розглянуто етапи впровадження навчального діалогу у процес вивчення іноземних мов як засобу формування мовленнєвої компетентності студентів технічних спеціальностей (зокрема майбутніх гірників); досліджено особливості чотирьох рівнів діалогізації навчання (базовий, проміжний, високий, професійний); надано практичні рекомендації, урахування яких допоможе уникнути помилок під час організації діалогічного навчання.

Ключові слова:навчальний діалог, мовленнєва компетентність, етапи діалогізації.

Бакум 3. П., Лапина В. А. Этапы введения учебного диалога в процесс изучения иностранных языков будущими горняками.

В статье рассмотрены этапы введения учебного диалога в процесс изучения иностранных языков как средства формирования речевой компетентности студентов технических специальностей (в частности будущих горняков); исследованы особенности четырёх уровней диалогизации обучения (базовый, промежуточный, высокий, профессиональний); предложены практические рекомендации, которые помогут избежать ошибок в организации диалогического обучения.

Ключевые слова:учебный диалог, речевая компетентность, этапы диалогизации.

Bakum Z. P., Lapina V. O. Stages of implementation of educational dialogue into the process of learning foreign languages by future miners.

The article describes the stages of introduction an educational dialogue into the process of learning foreign languages as means of forming speech competence of technical specialties students (future miners' competence); researches specifics of four levels of educational dialogue (basic, intermediate,upper-intermediate and advanced); contains practical recommendations, which will help to avoid mistakes in dialogic learning organization.

Key words: educational dialogue, speech competence, stages of entering a dialogue.

Реалізація євроінтеграційного курсу України передбачає інтенсивний розвиток міжнародних контактів, підтримання ділових стосунків 3 іноземними партнерами та ставить перед технічними вищими навчальними закладами нове завдання, яке полягає в нарощенні потужного освітнього потенціалу країни, вихованні нової генерації інженерно-технічних працівників, компетентнісне поле яких надзвичайно широке i сприяє інтенсифікації міжособистісних, міжнаціональних і міжнародних контактів. Відтак домінантою їх практичної галузі поряд із фаховою постає іншомовна комунікативна діяльність.

Підвищення якості іншомовної підготовки студентів технічних ВН3, зокрема майбутніх гірників, позиціонується як безальтернативна передумова забезпечення конкурентоспроможності вітчизняних випускників на світових ринках праці.

Сучасна школа все частіше апелює до впровадження в навчальний процес, особливо під час вивчення іноземних мов, активних форм, розглядає їх як основу професійного та особистісного розвитку (О. Абрамкіна, Л. Зазуліна, І. Зимня, 
О. Касаткіна, М. Максимець, Г. Цукерман та ін.). У низці досліджень (С. Батракова, М. Камінська, В. Кан-Калик, М. Кларін, К. Коновалова, В. Сєріков та ін.) відзначено, що тенденція розвитку активного навчання безпосередньо пов'язана 3 переходом до «суб'єкт-суб'єктної» парадигми освіти, яка розглядає навчальний процес як взаємодію багатьох суб'єктів та їх сенсів, полікультурний освітній простір.

Ідеї навчальної міжособистісної взаємодії суб'єктів педагогічної комунікації як носіїв різних сенсових позицій реалізуються через діалог, який видозмінює транслювальні (передавальні) форми навчання на діалогове подання змісту предмета шляхом його активного осмислення всіма учасниками освітнього середовища та глибокого аналізу викладачем і студентами власних розумових процесів, результатом чого є суб' єктивне знання - особистісно цінний інтелектуальний ресурс.

Аналіз наукових розвідок дидактичного потенціалу навчального діалогу доводить, що його освітні можливості насправді безмежні. Діалог у навчанні досліджують у різних контекстах: як спосіб організації навчання (О. Кондратюк, Л. Фролова); як організаційну форму навчальної діяльності (І. Зимня, М. Максимець, В. Сєріков); як ефективний дидактичний засіб формування суб'єктивного знання, тих чи тих навичок і вмінь (О. Абрамкіна, І. Глазкова, Т. Дикун, Н. Песняєва).

У процесі формування іншомовної професійно зорієнтованої мовленнєвої компетентності студентів - майбутніх гірників - навчальний діалог ми розглядаємо як ефективний дидактичний засіб накопичення, формування та розвитку суб'єктивних мовленнєвих знань, навичок і вмінь - особистісного мовленнєвого ресурсу (компетентності) через активізацію та реалізацію інтелектуального й творчого потенціалу учасників діалогічної взаємодії у форматі «викладач - студент (студенти)» або «студент - студент (студенти)», спрямованої на розв'язання проблемних навчально-комунікативних ситуацій на заняттях з іноземної мови.

Для максимальної реалізації всього дидактичного потенціалу навчального діалогу суб'єктам освітнього процесу, окрім володіння навичками діалогічного спілкування, необхідна ще й розвиненість умінь ведення саме діалогу, формування стратегії діалогічного навчання, що відбувається поетапно й порівнево.

Отже, метою статті є дослідження етапів уведення навчального діалогу у процес вивчення іноземних мов майбутніми гірниками та дослідження особливостей чотирьох рівнів діалогізації навчання.

Виокремлюємо чотири етапи діалогізації процесу іншомовної підготовки студентів технічних вищих навчальних закладів, які вирізняються видами та структурною складністю навчального діалогу (розпитування, домовленість, бесіда, диспут, дискусія тощо); організаційними формами (фронтальна, групова, парна робота, внутрішній діалог); завданнями (завдання-пастки, завдання без розв'язання, завдання 3 відсутніми даними тощо); форматом діалогічної взаємодії («викладач студент/студенти», «студент - студент/студенти»); ступенем керованості з боку викладача та рівнем студентської автономності; методами й прийомами; навчальним контекстом тощо.

Перший етап (базовий рівень) діалогізації процесу навчання передбачає базову підготовку студентів, формування початкової стратегії ведення навчального діалогу, формування навичок i вмінь діалогічного засвоєння матеріалу: ознайомлення 3 функціональними мовними зразками для організації продуктивної діалогічної взаємодії; формування вмінь вільного реплікування за допомогою нескладних за структурою діалогів 3 елементами навчального, навичок самостійного вживання діалогічних єдностей (ДЄ) і об’єднання їх у діалог; складання власних діалогів 3 
опорою і без опор; формування вмінь слухати й чути свого співрозмовника, виявляти до нього поважне ставлення; розвиток умінь соціальної перцепції та інших якостей, які допомагають своєчасно враховувати інтереси партнера під час діалогічної взаємодії, вибудовувати їі на суб'єктних засадах усіх учасників навчання.

Означений етап обмежується нескладними діалогами за структурою й рівнем комунікативної різноманітності реплік, що входять до їхнього складу, такими, як: діалог-розпитування, діалог-домовленість, діалог-бесіда- складаються переважно із запитань і повідомлень, які відбуваються в логічній послідовності й об'єднані розв'язанням однієї конкретної проблеми.

Діалогічна взаємодія 3 елементами навчального діалогу, що організовується на початковому етапі діалогізації процесу навчання іноземних мов, вирізняється високим рівнем керованості з боку викладача, який виконує переважно роль організатора, координатора: допомагає студентам окреслити проблемні питання; мотивує до активного пошуку ефективних шляхів їх розв'язання; надає підказки, наводить приклади для усунення ускладнень, пов'язаних із виконанням завдання; організовує обговорення результатів тощо. Студенти виконують роль суб'єктів навчання, однак переважно діють за зразком, пропонованим викладачем, поступово опановуючи стратегії діалогічного розв'язання означених навчальних проблем.

Основне завданням викладача на цьому етапі полягає в активізації діяльності студентів, перетворенні їх із пасивних спостерігачів, які виконують лише його вказівки, сприймають інформацію, що надходить від нього, на активних суб'єктів, партнерів, зацікавлених у власному розвитку й навчанні.

Другий етап (проміжний рівень) діалогізачії прочесу навчання іноземних мов передбачає організацію та проведення конструктивного навчального діалогу переважно у форматі «викладач - студент» задля формування у студентів ініціативної активної позиції під час діалогічної взаємодії, спрямованої на вивчення комунікативних ситуацій, пов'язаних із розв'язанням фахових проблем. Педагог частково контролює цей процес, студентам надається більша самостійність та ініціативність у навчанні. Основне завдання цього етапу - формування у студентів навичок i вмінь самостійного здобуття знань через активізацію інтелектуальних резервів і творчого потенціалу.

На другому етапі використовуються такі прийоми організації навчальної роботи, які провокують діалог між викладачем і студентами i тим самим сприяють формуванню і розвитку навичок діалогізації та іншомовного мовлення студентів, виховують у них спрямованість не на сприйняття зразків викладача, а на визначення студентської (власної) та викладацької позицій. Особливої уваги в цьому контексті заслуговують завдання-пастки, завдання без розв'язання, завдання з відсутніми даними, виокремлені Н. Песняєвою.

1. Завдання-пастки-виховують у студентів звичку довіряти собі й не вважати викладацьке слово істиною останньої інстанції. Викладач ставить запитання й, працюючи з групою, приєднується до неправильної відповіді, підкріплюючи її своїм авторитетом, або сам викладач пропонує помилкову відповідь. Студентам пропонується відкритий вибір: або погодитися 3 відповіддю викладача, або спростувати іiі й наполягти на своїй позиції, довести правдивість власної думки вагомими аргументами.

2. Завдання без розв'язання змушують студентів зрозуміти, що їх виконати неможливо; вони фіксують межу свого знання й незнання та зупиняються, відмовляючись діяти нерозумно. Такі завдання допомагають як викладачеві, так i 
студентам відрізнити навчальну поведінку, зорієнтовану на логіку (у цьому випадку відмова від розв'язання завдання), від «школярської старанності» (термін Г. Цукерман), зорієнтованої на буквальне розуміння слів викладача: «виконати це завдання». Студенти відкривають ще одну грань навчальних відносин - не буквальне ставлення до завдання.

3. Завдання з відсутніми даними культивують аналогічну лінію навчальних відносин на занятті. Такі завдання змушують студентів виходити за межі своїх знань на пошук невідомого, запитуючи потрібну інформацію, для отримання відсутніх даних у викладача. Подібні завдання є кількох типів: перший - це ті, розв'язання яких може здійснюватися в один спосіб після отримання відсутньої потрібної інформації; другий - завдання, що мають кілька способів розв'язання, але завдяки діям викладача, який регулює процес повідомлення необхідної інформації, розв'язуються однозначно (студенти повинні за допомогою запитань звузити коло пошуку й обмежитися єдиною відповіддю); третій тип завдань - багатоваріантні, коли студенти самостійно здогадуються про багатоваріативність розв'язання завдання й указують на це викладачеві [2].

Сутність запропонованих завдань полягає в тому, що навчальний процес організовується на засадах активної кооперативної діалогічної взаємодії всіх іiі учасників, де студент і викладач - рівноправні партнери, його суб'єкти. Завдання викладача полягає у здійсненні зворотнього зв'язку, в переорієнтуванні роботи групи за допомогою питань, у заохочуванні студентів до самостійного пошуку шляхів розв'язання проблем, що постають під час комунікації, усунення можливих конфліктів, надання довідкової допомоги тощо.

Ще одним прикладом організації продуктивної діалогічної взаємодії у форматі «викладач-студент» є навчальний діалог продуктивного нерозуміння, який змушує студентів, відмовившись від виконавчих установок, ставити запитання викладачеві для отримання необхідної інформації. Для того щоб студенти не лише опанували відповідну форму роботи «запитання-відповідь» (у ситуації прямої необхідності запитувати), а й самостійно шукали, чого саме вони не знають і не дізнаються без звернення до викладача, застосовуються ситуації відкритого незнання. Окрім уміння фіксувати межу свого знання й незнання та зупинятися біля цієї межі, відмовляючись діяти нерозумно, студентам потрібне вміння знайти можливість вийти за межі своїх знань на пошук невідомого. У студентів має сформуватися чітке переконання «Я цього не знаю, але можу дізнатися, якщо запитаю у викладача». Для цього необхідно навчити студентів «розумного запитування». Для формування вмінь ставити запитання задля отримання відсутньої інформації використовуються завдання, які розв'язуються кількома способами, але завдання студентів полягає в тому, щоб через запитання обрати один-єдиний правильний спосіб розв'язання.

Основними різновидами навчального діалогу на другому етапі діалогізації навчання іноземних мов $є$ діалог-бесіда ma діалог-дисnуm. Студенти під час розв'язання проблемного завдання висловлюються самі й розглядають усі наявні позиції, виконуючи ролі адресатів або адресантів. Відповідно, відбувається перетворення викладача з ролі помічники на діяча й навпаки.

Викладач виконує стимулювально-координаційну функцію: спонукає до діалогу, окреслює студенту умови й обставини, сприяє узгодженню загальної стратегії в діях студентів (уточнює, робить резюме, переформульовує висловлювання студентів тощо). Запитання викладача щодо нового знання спрямовані на з'ясування різних позицій студентів - предикації відомого у формі гіпотез, моделей тощо. На етапі, коли 
позиції відносно нового вичерпано й визначено, викладач перевтілюється 3 ролі помічника в активного суб'єкта й озвучує подальший перебіг бесіди, приймає участь у вирішальній стадії діалогу вже як діяч.

Третій етап (високий рівень) діалогізації проиесу навчання - організація та проведення повноцінного навчального діалогу переважно у форматі «студентстудент», який характеризується рівністю й активністю всіх пї учасників як повноцінних суб'єктів навчального процесу. Викладач з інформатора переходить у позицію партнера у здобутті знань, постає не простим спостерігачем, консультантом, а безпосереднім активним учасником процесу пізнання; студент як суб'єкт навчання виявляє пошукову активність, наполегливо працює над своїм інтелектуальним зростанням і всебічним розвитком, усіляко прагне розкриття власного потенціалу та розумових можливостей.

Основним різновидом навчального діалогу в межах третього етапу діалогізації процесу навчання іноземних мов є дискусія, що характеризується високим рівнем структурної складності й великою різноманітністю реплік. Особливістю цього типу діалогу є те, що він передбачає участь більше, ніж двох співрозмовників, погляди яких щодо обговорюваної проблеми можуть різнитися. Усе це вимагає від учасників толерантності у взаємовідносинах, сформованості вмінь слухати й чути свого співрозмовника, виявляти до нього поважне ставлення, соціальну перцепцію, вибудовувати продуктивну суб'єкт-суб'єктну діалогічну взаємодію.

Динаміка такого діалогу вибудовується на з'ясуванні й розумінні різних думок щодо теми обговорення; затвердженні одних позицій за рахунок спростування інших як недієздатних організувати виконання загальної предметної дії; на координації позицій. Цей вид навчального діалогу є найбільш продуктивним, оскільки грунтується на принципах самостійного відкриття й формулювання студентами наукового знання.

I. Сімкова пропонує таку структуру навчання діалогу-дискусії: інформативнопідготовчий, ситуативно-дискусійний, констатувально-інтерпретаційний етапи (табл. 1)[3].

Табличя 1

Етапи навчання діалогу-дискусії

\begin{tabular}{|c|c|c|c|}
\hline Етапи & $\begin{array}{c}\text { Інформативно- } \\
\text { підготовчий }\end{array}$ & $\begin{array}{l}\text { Ситуативно- } \\
\text { дискусійний }\end{array}$ & $\begin{array}{l}\text { Констатувально- } \\
\text { інтерпретаційний }\end{array}$ \\
\hline $\begin{array}{l}\text { Компо- } \\
\text { ненти }\end{array}$ & $\begin{array}{l}\text { експозиція; } \\
\text { переддискусія; } \\
\text { уточнення понять; } \\
\text { повідомлення і пошук } \\
\text { основної інформації; } \\
\text { повідомлення додаткової } \\
\text { інформації. }\end{array}$ & $\begin{array}{l}\text { аргументація; } \\
\text { проведення } \\
\text { дискусії. }\end{array}$ & $\begin{array}{l}\text { формулювання } \\
\text { висновків; } \\
\text { аналіз дискусії. }\end{array}$ \\
\hline
\end{tabular}

Реалізація окреслених етапів навчання дискусії може відбуватися в межах одного заняття, але інколи виникає необхідність розподілити етапи на кілька практичних занять. Задля інформаційного озброєння студентів підготовчий етап відокремлюють від ситуативно-дискусійного. Щоб досягти максимальної продуктивності під час дискусії, студентам пропонують самостійне опрацювання дискусійної проблематики в домашньому режимі. Пізнавально-пошукова позааудиторна робота $є$ однією із форм організації підготовчого етапу дискусії.

Два інших етапи навчання дискусії переважно реалізуються в межах одного 
практичного заняття, оскільки ï проведення й аналіз (ситуативно-дискусійний), формулювання висновків (констатувально-інтерпретаційний) є логічно пов'язаними етапами, які бажано не розділяти задля збереження інформації, отриманої під час обговорення, для кращого подальшого аналізу дискусії та формулювання висновків. Проте бувають і винятки: у випадках, якщо констатувально-інтерпретаційний етап $€$ контрольним i узагальнювальним для попередніх обговорень. Отже, викладач самостійно вирішує, як краще розподілити етапи навчання діалогу-дискусії, виходячи 3 практичних намірів, навчальної ситуації, мети занять та індивідуальних особливостей студентів.

Четвертий етап (професійний рівень) діалогізації передбачає остаточне закріплення/шліфування сформованих на попередніх етапах навичок i вмінь діалогічного навчання. Викладач і студенти - рівноправні партнери, активні суб'єкти навчальної діяльності.

Навчальний контекст проблемно-комунікативних ситуацій, що передбачають розв'язання проблем у формі діалогічної взаємодії, на всіх етапах діалогізації зумовлюється змістом і метою академічних модулів, спрямованих на формування одного з трьох (соціально, професійно, бізнес зорієнтованих) компонентів іншомовної професійно зорієнтованої мовленнєвої компетентності студентів.

Вибір організаційних форм на тому чи тому етапі діалогізації процесу вивчення іноземних мов майбутніми гірниками зумовлюється низкою дидактичних чинників, таких, як індивідуальні можливості суб'єктів навчання, мета, завдання тощо. На заняттях з іноземної мови слід надавати перевагу тим формам навчального діалогу, які мають найбільший потенціал для ефективної організації єдиного комунікативного простору. До таких форм відносимо груповий, парний та внутрішній діалоги, які сприяють продуктивній діалогічній взаємодії суб'єктів навчальної діяльності, під час якої студенти набувають навичок вільного й самостійного вибору відповідних способів розв'язання навчальних завдань, формують уміння організації діалогових взаємовідносин, отримують досвід іншомовного спілкування, підвищуючи рівень відповідних мовленнєво-комунікативних компетентностей.

Варто уникати такої форми діалогу, як фронтальне навчання, оскільки досвід показує, що лише 25-35\% студентів залучаються до розв'язання нав'язаного викладачем завдання, інші 75-65\% взагалі не задіяні в цьому процесі. Більшість студентів діють тільки за звичкою «бути хорошим, старанним, відповідальним», а не тому, що завдання їх зацікавило. Привчені діяти «за прикладом», вони не здатні до самостійної діяльності, завжди сподіваються на підтримку дорослих. Відсутність самостійності та незалежної самокритичності- ось наслідок фронтальної форми діалогу. Але повністю уникнути цієї форми діалогу на заняттях практично неможливо, оскільки на деяких етапах вона $є$ досить дієвою.

Що ж до методів $i$ прийомів організації навчального діалогу як засобу формування іншомовної професійно зорієнтованої мовленнєвої компетентності майбутніх гірничих інженерів, найбільш дієвими $є$ ті, що сприяють залученню студентів до активної пізнавально-пошукової діалогічної взаємодії; навчають виконання різних функцій під час групової або парної роботи: домовлятися 3 одногрупниками, ставити й розв'язувати навчальне завдання, моделювати спосіб дій i перевіряти його дієвість на конкретних прикладах, робити рефлексивне оцінювання роботи групи в цілому та кожного члена групи окремо, формулювати нове знання, отримане як результат колективно-розподіленої навчальної діяльності тощо.

Ми переконані, що розглянута вище схема поетапної діалогізації навчання іноземних мов, яка передбачає поступове формування відповідних навичок та вмінь, 
необхідних знань і стратегій діалогічної взаємодії, сприяє підвищенню ефективності процесу формування іншомовної професійно зорієнтованої мовленнєвої компетентності студентів - майбутніх гірників через максимальну реалізацію дидактичного потенціалу навчального діалогу.

\section{Література}

1. Бакум 3. П. Теоретико-методичні засади навчання фонетики української мови в гімназії: [монографія] / Зінаїда Павлівна Бакум. - Кривий Ріг : Видавничий дім, 2008. - 338 с. 2. Песняева Н. А. Учебный диалог как средство развития речевой деятельности младших школьников : дис. ... канд. пед. наук : 13.00.01/ Наталья Александровна Песняева. - Москва, 2004. - 214 с. З. Сімкова І. О.Комплекс вправ для формування професійно орієнтованої мовленнєвої компетенції в діалогічному мовленні у студентів інженерних спеціальностей / I. О. Сімкова // Іноземні мови. 2009. - № 3. - С. 23-26.

УДК [378.011.3-051:811]:004

Маріанна Бедевельська

\section{ПЕДАГОГІЧНІ УМОВИ ЕФЕКТИВНОСТІ ПІДГОТОВКИ МАЙБУТНІХ УЧИТЕЛІВ ІНОЗЕМНИХ МОВ}

Бедевельська М. В. Педагогічні умови ефективності підготовки майбутніх учителів іноземних мов.

У статті визначено й теоретично обгрунтовано педагогічні умови дієвості педагогічної технології формування педагогічної майстерності майбутніх учителів іноземних мов на засадах компетентнісного підходу: створення мотиваційного середовища, упровадження особистісно орієнтованого i проблемного навчання, забезпечення професійної адаптації.

Ключові слова: педагогічна майстерність, компетентнісний підхід, технологія підготовки майбутніх учителів іноземних мов, педагогічні умови.

Бедевельська М. В. Педагогические условия эффективности подготовки будущих учителей иностранных языков.

В статье определены и теоретически обоснованы педагогические условия действенности педагогической технологии формирования педагогического мастерства будущих учителей иностранных языков на базе компетентностного подхода: создание мотивационной среды, внедрение личностно-ориентированного и проблемного обучения, обеспечение профессиональной адаптации.

Ключевые слова: педагогическое мастерство, компетентностный подход, технология подготовки будущих учителей иностранных языков, педагогические условия.

Bedevelska M. V. Pedagogical conditions efficiency preparation of future foreign languages teachers.

In the article pedagogical conditions efficiency of pedagogical technology of formation pedagogical mastership of foreign language teachers on the competence-based approach is determined and theoretically grounded: creating a motivational environment, implementation of student-centered and problem-based learning, vocational adaptation.

Key words: pedagogical mastership, competence approach, technology of training of future foreign language teachers, pedagogical conditions.

Важливими проблемами сьогодення, які покликана розв'язувати вища школа, $є$ 